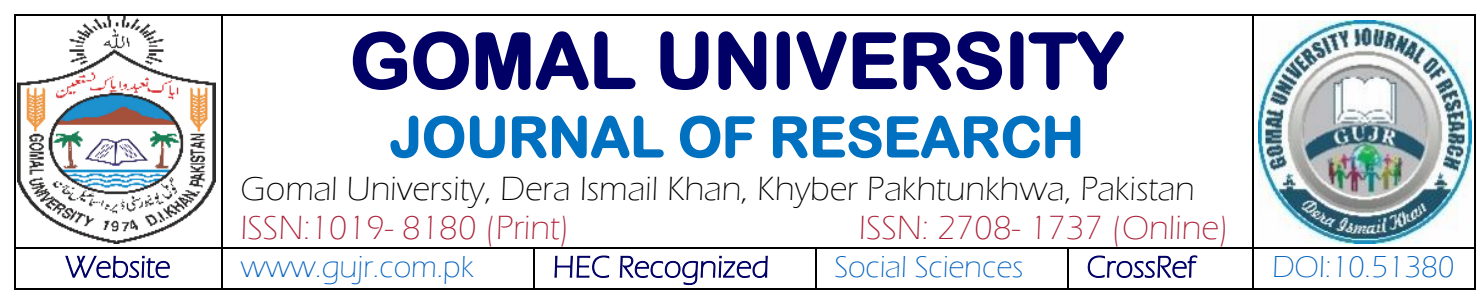

\title{
THE IMPACT OF ADMINISTRATORS ON TEACHER RETENTION AT PRIVATE SECONDARY SCHOOLS IN PAKISTAN
}

\author{
Nomana Tariq' ${ }^{1}$ Imran Yousuf² \& Fouzia Ajmal ${ }^{3}$ \\ 'PhD Scholar, Department of Education, Allama Iqbal Open University Islamabad, Pakistan \\ 2Division of Continuing Education, PMAS-Arid Agriculture University, Rawalpindi, Pakistan \\ ${ }^{3}$ Department of Education, International Islamic University, Islamabad, Pakistan
}

\section{\begin{tabular}{l|l} 
KEYWORDS & ABSTRACT
\end{tabular}}

Teachers' Retention, Working Environment,

Facilities, Private

Schools

\section{Article History}

Date of Submission:

11-10-2020

Date of Acceptance:

17-09-2021

Date of Publication: 30-09-2021
It is a crucial issue to retain highly qualified educators to provide high quality education in private schools. High turnover of educators in private schools has a negative impression on the pupil satisfaction and on their educational progress as well. Retention of educators refers to retaining qualified and efficient teachers in schools for a long time. As recruitment is a complex process for the selection of qualified and competent teachers so, retention of teachers is most crucial and extensive issue for private schools in of Pakistan. The present research study was conducted to explore the impacts of school's administrations on educators' retention at the private schools in Pakistan. The descriptive statistics and t-test statistical tools were applied to assess collected data with respect to school's administrations, their behavior and facilities. The findings of the study based on the Likert scale indicated that most of teachers were not satisfied with their school's administration, their behaviors and facilitation. T-test analysis indicated that no significance difference was found between the retention intentions of male and female teachers.

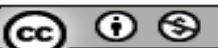

Fouzia Ajmal: fouzia.ajmal@iilu.edu.pk

Corresponding Author

https://doi.org/10.51380/gujr-37-03-08

\section{INTRODUCTION}

Quality of learning in any National State shows quality of its human resources. Advanced States spend large portion of their budget on the educational activities of their public. Thus, developed countries provide free education or the minimum cost of education for their people (Tehseen \& Hadi, 2015). Educational expenditure is considered as investment in form of human resources (Government of Pakistan, 2009). The recruitment of highly qualified and effective educators is the obligation of entire society (Schaefer, Long \& Clandinin, 2012). The process of recruitment includes searching for the qualified and effective candidates, investigating the needs of the job, fascinating the personnel, screening and choosing candidates, hiring and integrating the new 
employees in a time and cost-effective means for organization (Akram \& Bilal, 2013; Campoli, 2017). In this connection, the researchers are now focusing on investigating the administrative characteristics, especially the role of principals, in resolving key issues of teacher retention and loss. Charlotte Advocates for Education, (2004) searched the existing literature through diverse studies from national and indigenous contexts, studied problem of educator retention for several years, and stated that the poor working circumstances influenced teacher retention decisions factor.

The teachers surveyed stated that the leadership of the principal is essential to creating a sustainable and positive school environment. Evidence is available that teachers did not leave a bad school, but a bad principal (Charlotte Advocates for Education, 2004; Cieminski, 2018). When researchers look at retention rates, key influencers which are likely to extend teachers' time in the profession are aspects such as gratitude and sustenance, a situation that nurtures teacher college learning openings and a school culture where coaching for attainment is in place (Darling-Hammond, 2003; Huysman, 2007; Akilli \& Kingir, 2021). School management is the essential component of educational institution that plays significant role from different scopes toward development. The principal is key role in producing specialized environment. Principals also play an important role in retaining highly qualified educators through a number of activities including providing support and communal sense of governance to the educators, identifying and gratifying educator achievements, supporting educator professional development and offer the chances to share professional knowledge (Hughes, Cao, West, Smith \& Cerda, 2017).

\section{LITERATURE REVIEW}

According to Akram and Bilal (2013) mostly teachers leave an organization when they are not satisfied with adjustments to their working conditions. Moreover, lack of organizational support is a big reason for employees to switch to another organization. The factors of dissatisfaction of teachers includes the poor working conditions, low salary, administration behavior, discipline, management, the impact of absentees, increasing class size, increasing workload, lack of the motivation of students. Another main issue in the educational institutions is that they are not involving the teachers in taking the important decisions which affect their working lives. A further key problem is the lack of training programs, workshops and effective mentoring for new teachers (Long et al., 2012). The imperative issue is therefore retaining teachers after their recruitment to the schools, including the private, schools. Administrations of the educational institutions need to apply effective strategies and policies related to teachers' recruitment and retention (Shifrer, Turley \& Heard, 2017). Some policies that support the recruitment and retention process give rewards to the teachers for their retention, but this is difficult due to cost issue.

Teacher retention issues which need to be tackled include: mechanisms underlying unfavorable working conditions, the lack of access to advanced technologies, incentives, a lack of motivation both from the school's administration and students, salary, loans, an unsafe future, a lack of promotions and the stressful working environment. Factors such as these make the teaching profession less attractive than other professions (Bolapeju et al., 2018). The organizations try to stop these effective teachers leaving by giving them a better salary and benefits (Hughes et al., 2017). Ferlazzo (2015) proposed that educators do not leave hard to staff schools; they are merely displaced. In this connection, the educators are displaced by fractious decision-making 
structures, lack of support by school leaders and administrations and by policy priorities that do not focus on the pupil learning and developing professional learning environments and communities. It is also suggested that good educators leave because no one asks them to stay. Educators also leave because of lack of admiration. In thisregard, Riggs (2013) described that educators leave schools due to universal disregard and the incapability to effect the academic decisions.

In another investigation of influences of administrative support on educator retention Kimball (2011) proposed that school leadership and administrations affects retention from a position of human capital management, with the definitive goal being school progress and improvement. Principals understand that simply handing educators the classroom keys and challenging them with accountability for the learner achievements within these classrooms is counterproductive to school improvement, educator performance and retention. The research study also indicated that a well-established system keen to manage the performance and achievements, which also contains the formal setting of goals and objectives, facilitated access to support and mentoring, ongoing feedback and acknowledgement of the actions, as well as the repercussions for poor performance were critical indicators of the educators' attitudes toward the nexus of leadership support and the retention decisions. The research shows that the teaching is a very traumatic profession (Jing, 2008; Gomba, 2015; Hughes et al., 2017; Nguyen et al., 2019; Arroyo, 2020; Fessehatsion \& Peng, 2021). According to Chance (1992) teacher stress, which teaching for a long time in the schools creates, may cause mental and physical health issues for the concerned teachers.

Many studies regarding work stress illustrate importance of: differences among environments, situational working factors in employees, unavailability of resources and inability of workers to organize them (Lazarus \& Folkman, 1984; Edworthy, 2000; Oke et al., 2016; Watson, 2018). Akila (2012) said that employee retention is course of action in which employees are supported in having an expectation to be a part of organization so that he $\backslash$ she is retained in organization. The retention of workers is equally important for both the employees and institution (Mugizi \& Dafiewhare, 2019; Roseoooy \& Sughrue, 2020). There is employer responsibility and capability needed to retain competent workers, otherwise they will leave the organization and, as a result, organization will lose good employees. Samuel and Chipunza (2009) say that aim of retention is to prevent the organization from a loss of employees. Otherwise, when workers leave, there will be consequently negative effects on organizational production and success. Godfrey (2010) reported that perceived organizational support is a negative point that connects with turnover intentions of employees. Employees will be more devoted and stay in that organizations for a longer time where their efforts are recognized and they are provided with a comfortable work environment.

Price (2001) and Sousa-Poza \& Henneberger (2004) defined the "turnover intention" as level at which employees decide they will stay or leave the organization. The turnover intention has two aspects related to turnover, positive and negative. If the progress of workers is not good then their mobility may actually be better for an organization whereas if competent employees move on to another workplace this can be the risk to the organization (Cascio, 2010, Opoku et al., 2020). There are factors directly and indirectly associated to costs of turnover, such as: direct costs related to replacement, hiring new employees and their training. On other hand, indirect costs are associated with losing capable and productive workers from organization (Lambersky, 
2016; Rana, 2018). Thus, the successful private schools focus on the teacher quality and strong leadership related to improving the educational outcomes for all students, because competent teachers affect student academic achievement (Bogler \& Nir, 2015; Van Overschelde \& Wiggins, 2020). Better recruitment and effective selection strategies result in improving organizational outcomes.

The more effective policies and strategies related to teachers' recruitment apply to improving the satisfaction and hence, also retention of these teachers. Hence, for the development of an organization and its people we need expenditure for the better future of the organization as an investment (Pogodzinski, 2015; Singh et al., 2018). The present research study explored the impacts of school administrations, their behavior and facilitation on the teacher's retention at Private Schools in Pakistan. The study purposes to determine the desired evidence about the administration of the schools and teachers' behavior problems related to teachers' retention in the organization. The conclusions of this research study would be significantly beneficial for: the respondents of the study, teachers and administration of the educational institutions, the higher education, educational practitioners, the educational planners and policy makers. This study may be helpful in identifying different barriers to retaining employees. Moreover, this study provides support to the newly appointed teachers and already existing teachers in any organization.

\section{RESEARCH METHODOLOGY}

The research study is a descriptive survey in nature using a quantitative method through the development of questionnaires. The quantitative data were collected from the teachers through questionnaires with items related to retention issues of private schools teachers in Pakistan. The study was delimited to secondary level teachers of private schools in district Rawalpindi, Pakistan.

\section{Population \& Sample}

The population of the study comprised all the teachers of private schools in Rawalpindi district. The permission for data collection was taken from District Education authority mentioning the objectives of the study. After that school heads were contacted for data collection. Around 90\% responded positively for collecting data for this study. Purposive sampling technique was used to draw sample. Fifteen schools were selected purposively and from each school twenty teachers were selected randomly. A total sample of 300 teachers from private schools in Rawalpindi city were available for study. Teachers were teaching mathematics and physics from previous three years.

\section{Tool of Research}

The study is descriptive in nature. The questionnaire was considered as a suitable tool for this research. The questionnaire contains three aspects of retention related to teachers in private sector. The items were designed after looking at the relevant literature. In this connection, the questionnaire was pilot tested on the small sample of the population before collecting the data, when it was discussed with teachers and experts for the purpose of improving questionnaire. Thus, some items were removed and changes were made in the questionnaire after the pilot testing. 


\section{Data Analysis}

Mean scores of each item were used to analyze data. Questionnaires were used for data collection from teachers which consisted of 20 items. Each item was constructed on the five-point Likert Scale which had five options namely; Strongly Agree $(\mathrm{SA})=1$, Agree $(\mathrm{A})=2$, Uncertain $(\mathrm{UNC})=3$, Disagree $(D)=4$, Strongly Disagree $(\mathrm{SDA})=5$. The data was summarized using the descriptive statistical methods, involving calculating the arithmetic mean and variation around this mean. The gender difference was calculated through an independent sample t-Test. The Arithmetic Mean also called as average is the ratio of all the observations to the total number of the observations. In this connection, the arithmetic mean can also model concepts outside of the statistics.

\section{Calculation of Arithmetic Mean}

To find the arithmetic mean, add a collection of numbers and divide the sum by the count of the numbers in that collection. The mathematical expression is given below: Where,

$$
\text { Arithmetic Mean }=\frac{a_{1}+a_{2}+a_{3}+\ldots+a_{n}}{n}=\sum_{i=1}^{n} \frac{a_{i}}{n}
$$

ai - The value of the ith observation:, $n$ - The number of observations:, Significance of Mean for Likert Scale data

The arithmetic mean or simply average is often used to classify central position of distribution of group of data. The importance for arithmetic mean for Likert scale is that its value represents the extent of the statement of Likert scale. These may be represented as: 1 to 1.80 represents (strongly disagree), 1.81 until 2.60 represents (do not agree), 2.61 until 3.40 represents (true to some extent), 3:41 until 4:20 represents (agree) and also 4:21 until 5:00 represents (strongly agree).

\section{RESULTS AND DISCUSSION}

The present study was conducted to determine administration effects of working environment on teacher retention in private schools, from perspective of teachers in the Rawalpindi district of Pakistan. The statistical analyses of data, indicating the percentages of responses per level of the Likert scale, the arithmetic mean and the variation indicated as the standard deviation (SD) are shown in Table 1.

\section{Table 1}

Teachers' Retention with respect to Administration

\begin{tabular}{|c|c|c|c|c|c|c|c|}
\hline \multirow[t]{2}{*}{ Item } & \multicolumn{5}{|c|}{ \%age of Responses } & \multirow[t]{2}{*}{ Mean } & \multirow[t]{2}{*}{ SD } \\
\hline & SA & $\mathrm{A}$ & UNC & $\mathrm{D}$ & SDA & & \\
\hline $\begin{array}{l}\text { The school administration has a clear vision for the } \\
\text { school. }\end{array}$ & 13.4 & 41.1 & 26.4 & 15.4 & 3.7 & 2.5 & 1.0 \\
\hline $\begin{array}{l}\text { The school administration talks with teachers } \\
\text { frequently about their teaching method. }\end{array}$ & 8.7 & 42.5 & 29.8 & 15.4 & 3.7 & 2.6 & 1.0 \\
\hline $\begin{array}{l}\text { The school administration gives great opportunity for } \\
\text { promotion. }\end{array}$ & 12.4 & 36.8 & 24.8 & 22.1 & 4.3 & 2.7 & 1.1 \\
\hline $\begin{array}{l}\text { The school administration provides professional } \\
\text { development programmed for teachers. }\end{array}$ & 21.7 & 41.8 & 16.4 & 12.4 & 7.7 & 2.4 & 1.2 \\
\hline $\begin{array}{l}\text { The school administration demands hard work at } \\
\text { recruitment level. }\end{array}$ & 11.0 & 46.5 & 19.7 & 20.4 & 2.3 & 2.6 & 1.0 \\
\hline
\end{tabular}


The school administration put extra work on teachers. The school administration does discrimination among 13.0 teachers.

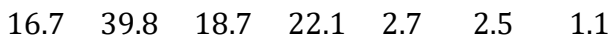

The overall school performance is good as compared

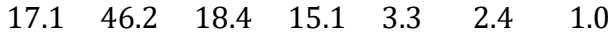
to other private schools.

\begin{tabular}{lllllllll}
\hline Administrators provide feedback to the teachers at the & 12.0 & 46.2 & 18.1 & 17.7 & 6.0 & 2.6 & 1.1
\end{tabular}
end of educational task

Table 1 depicted teachers' views of aspects of teachers' retention with respect to administration at secondary level of private schools. It is evident from the responses of teachers that $13.4 \%$ respondents strongly agreed that administration has a clear vision about their own school and $14.1 \%$ respondent agreed with statement. Around $15.4 \%$ disagreed and $3.7 \%$ strongly disagreed with this statement whereas $26.4 \%$ teachers were found uncertain in this regard. The calculated mean value (2.5) also showed that respondents have a clear vision about their school. It was clear from the data that most of the teachers $(51.2 \%)$ strongly agreed or agreed that school administration talks with teachers frequently about their teaching method. On the other hand, there were a small proportion (3.6\%) of respondents who disagreed or strongly disagreed that the school administration did not talk with teachers frequently about their teaching method, while $29.8 \%$ respondents answered as uncertain. The computed mean value (2.6) supported the positive responses of teachers that they wanted school administration to talk or discuss with teachers frequently about their teaching methods. Table 1 also showed that $12.4 \%$ teachers were strongly agreed and $36.8 \%$ were agreed to the question related to the problem of school administration giving opportunities for promotion, whereas $22.1 \%$ were disagreed and $4.3 \%$ were strongly disagreed in being helped in this regard. $24.8 \%$ teachers remained uncertain. The calculated mean value, which at 2.7 was highest mean recorded, also indicates the dominance of positive responses (strongly agreed and agreed), with the little tendency towards uncertain responses.

From the evaluated responses of teachers related to the private school administration provision of professional development programs for teachers, $21.7 \%$ teachers strongly agreed and $41.8 \%$ respondent agreed with this statement. Though, $12.4 \%$ respondents disagreed and $7.7 \%$ teacher strongly disagreed from this point of view that their private school's administration provided professional development programmed for teachers. $16.4 \%$ respondents were uncertain and the computed mean value was 2.4. 11.0\% respondents agreed about the school administration demanding hard work at recruitment level, with $20.4 \%$ teachers responding in the opposite and a further $19.7 \%$ respondents not giving their decision as either positive or negative. The evaluated mean (2.6) of item clarified that the respondents generally offered positive (agreed) responses with a minor tendency towards uncertain responses. Table 1 represented that $13.0 \%$ teachers strongly agreed that the school administration gives a high workload to teachers, with a further $57.9 \%$ respondents agreeing to this point of view. Contrary to that, $17.7 \%$ respondents disagreed and $3.0 \%$ teachers strongly disagreed that private schools did not give high workload to teachers. At the same time $8.4 \%$ of respondents replied as uncertain. The mean score (2.4) indicated that majority of respondents not consider extra workload to be a key issue for them as teachers.

The tabulated data in Table 1 showed that $16.7 \%$ teachers strongly agreed and $39.8 \%$ teachers agreed with the question that the school administration does discriminate amongst teachers. 
Whereas, 22.1\% teachers disagreed and 2.7\% strongly disagreed with this statement. $18.7 \%$ teachers remained uncertain. It is clear from Table 1 that most (63.3\%) teachers strongly agreed/agreed that their school's performance was good as compared to other private schools. There was a small proportion (18.4\%) of respondents who disagreed or strongly disagreed, while $18.4 \%$ respondents answered as uncertain. The responses of teachers to the statement about the administrators providing feedback to the teachers at the end of educational tasks were that $12.0 \%$ respondents agreed, $6.0 \%$ teachers responded in the opposite and $18.1 \%$ respondents did not give their decision as either positive or negative. The evaluated mean (2.6) of the item clarified that respondents were generally positive (agreed), with a minor tendency to uncertain responses.

\section{Table 2}

Teachers' Retention with respect to Behavior

\begin{tabular}{|c|c|c|c|c|c|c|c|}
\hline Item & \%age & of Res & onses & & & Mean & SD \\
\hline & SA & A & UNC & D & SDA & & \\
\hline $\begin{array}{l}\text { The Principal's behavior is cooperative in dealing } \\
\text { with teachers. }\end{array}$ & 17.4 & 49.8 & 15.7 & 13.7 & 3.3 & 2.4 & 1.0 \\
\hline Teaching staff is cooperative with each other & 21.7 & 37.1 & 20.7 & 17.4 & 3.0 & 2.4 & 1.1 \\
\hline $\begin{array}{l}\text { Teachers are changed due to administrative problems } \\
\text { frequently. }\end{array}$ & 5.0 & 41.5 & 27.8 & 17.7 & 8.0 & 2.8 & 1.0 \\
\hline $\begin{array}{l}\text { The school administration takes immediately reaction } \\
\text { on any problem of the school. }\end{array}$ & 13.0 & 45.5 & 28.8 & 10.7 & 2.0 & 2.4 & 0.9 \\
\hline $\begin{array}{l}\text { Administrative ignore the student misbehavior with } \\
\text { teachers. }\end{array}$ & 9.4 & 48.5 & 17.7 & 16.7 & 7.7 & 2.6 & 1.1 \\
\hline
\end{tabular}

Table 2 elaborated that aspects of teachers' retention with respect to behavior problems at the secondary level in private schools in Rawalpindi district. It is shown from teachers' responses that $67.2 \%$ respondents strongly agreed or agreed that the Principal's behavior is cooperative in dealing with teachers. On the other hand, $13.7 \%$ respondents disagreed and $15.7 \%$ teachers had an uncertain point of view regarding this statement. The mean calculated value (2.4) also showed that mostly principals' behavior is cooperative in dealing with teachers. In this regards, table 2 also represented that $\mathbf{2 1 . 7} \%$ teachers strongly agreed that the teaching staff of private schools is cooperative with each other and $37.1 \%$ respondents also agreed with this point of view. Contrary to that, $17.4 \%$ respondents disagreed and $3.0 \%$ teachers strongly disagreed that the teaching staff of private schools is cooperative with each other. At the same time $20.7 \%$ of the respondents replied as uncertain. In thi connection, the mean score (2.4) showed that the teaching staff of private schools do not behave in good manner and are not supportive for each other.

Table 2 showed that $5.0 \%$ teachers strongly agreed and $41.5 \%$ teachers agreed with statement that teachers are changed due to administrative problems frequently. $17.7 \%$ teachers disagreed and $8.0 \%$ strongly disagreed with this statement. $27.8 \%$ teachers remained uncertain. The calculated mean value (2.8) also showed that tendency of positive responses was strongly agreed and agreed. It is also obvious from the table 2 that $13.0 \%$ respondents strongly agreed about the school administration takes the immediately action to any problem of the school and $45.5 \%$ respondents were agreed. On the other hand, $10.7 \%$ respondents disagreed and $2.0 \%$ strongly disagreed that administration takes serious action related to any behavior problems in the 
schools, with $28.8 \%$ respondents uncertain. It is clear from data that $57.9 \%$ teachers were strongly agreed or agreed with problem that administration ignore student misbehavior with teachers, with a smaller proportion (24.4\%) of respondents disagreeing or strongly disagreeing. 17.7\% respondents were answered in uncertain. The computed mean value (2.6) showed that, overall, the administration of the private schools tended not to ignore the misbehavior of students with teachers.

\section{Table 3}

Teachers' Retention with respect to Facilities

\begin{tabular}{|c|c|c|c|c|c|c|c|}
\hline \multirow[t]{2}{*}{ Item } & \multicolumn{5}{|c|}{ \%age of Responses } & \multirow[t]{2}{*}{ Mean } & \multirow[t]{2}{*}{ SD } \\
\hline & SA & A & UNC & $\mathrm{D}$ & SDA & & \\
\hline $\begin{array}{l}\text { The school administration is supportive to provide } \\
\text { medical facilities to encourage teachers. }\end{array}$ & 14.7 & 45.5 & 11.0 & 19.1 & 9.7 & 2.6 & 1.2 \\
\hline $\begin{array}{l}\text { The school environment is comfortable for } \\
\text { adjustment of teachers. }\end{array}$ & 19.1 & 49.5 & 20.7 & 7.0 & 3.7 & 2.3 & 1.0 \\
\hline $\begin{array}{l}\text { The school administration offered salary package is } \\
\text { satisfactory. }\end{array}$ & 6.4 & 51.5 & 16.7 & 21.4 & 4.0 & 2.7 & 1.0 \\
\hline $\begin{array}{l}\text { The school administration gives rewards or any } \\
\text { incentives to your great performance. }\end{array}$ & 10.0 & 37.8 & 20.7 & 26.1 & 5.4 & 2.8 & 1.1 \\
\hline $\begin{array}{l}\text { The school administration provides instructional } \\
\text { material on your requirement. }\end{array}$ & 20.7 & 45.8 & 17.7 & 15.1 & 0.7 & 2.3 & 1.0 \\
\hline $\begin{array}{l}\text { The school management provides facilities with good } \\
\text { salary for every teacher. }\end{array}$ & 5.0 & 9.1 & 12.4 & 65.1 & 3.3 & 2.9 & 2.2 \\
\hline
\end{tabular}

Table 3 explained the teachers views of teacher retention with respect to provision of facilities. It is evident from responses of teachers that $14.7 \%$ strongly agreed that school administration is supportive in providing medical facilities to inspire teachers and $45.5 \%$ respondents agreed with this statement. Contrary to that $\mathbf{1 9 . 1 \%}$ teachers disagreed and $9.7 \%$ strongly disagreed. $11.0 \%$ respondents reported to be uncertain. The average calculated value (2.6) pointed out that the private schools tended to provide medical facilities to the teachers for their health support. It is shown in Table 3 that $19.1 \%$ teachers strongly agreed that the school environment is comfortable for the adjustment of teachers and 49.5\% teachers agreed with this. On the other hand $7.0 \%$ respondents disagreed and $3.7 \%$ strongly disagreed, whereas $20.7 \%$ teachers were uncertain about comfortable environment for adjustment of the teachers. It is obvious from Table 3 that $5 \%$ respondents strongly agreed that school administration salary package is satisfactory and $9.1 \%$ respondents agreed. On the other hand, 12.4\% respondents disagreed and $65.1 \%$ strongly disagreed that the private schools give a good package of salary, whereas $3.3 \%$ respondents found uncertain from this point. In thi regard, the calculated mean value (2.7) also determined that the said teachers of the private schools are not satisfied with their current salaries.

Table 3 also showed that $10.0 \%$ teachers strongly agreed and $37.8 \%$ teachers agreed with the statement that private school administration gives rewards or incentives to reward teachers' performance. Whereas, the $26.1 \%$ teachers disagreed and $5.4 \%$ strongly disagreed with this statement. 20.7\% teachers remained uncertain. The calculated mean value (2.8) showed that mostly the private schools gave rewards or incentives to the teachers for their extra educational performance related to teaching methods. It is clear from the data that $66.5 \%$ teachers were 
strongly agreed or agreed regarding the provision by school administration of the instructional material to meet teachers requirements, with a small ratio of $15.8 \%$ respondents disagreeing or strongly disagreeing. $\mathbf{1 7 . 7 \%}$ respondents answered as uncertain. Table 3 also showed that 10.0\% teachers strongly agreed and $34.1 \%$ teachers agreed with the question about the school management's provision of a good salary for every teacher. Whereas, $34.1 \%$ teachers disagreed and $3.3 \%$ strongly disagreed with this statement. $18.4 \%$ teachers remained uncertain. The calculated mean value (2.9) showed strong evidence that private schools provide strong salary package.

\section{Table 4}

T-test Analysis of Gender Differences

\begin{tabular}{lcll}
\hline Gender & Numbers of Teachers & Mean score & p value \\
\hline Female & 150 & 2.945 & 0.625 \\
\hline Male & 150 & 3.00 & \\
\hline
\end{tabular}

Statistically significant at the significance level of 0.05 .

Table 4 shows the independent sample t-Test regarding gender differences in retention related challenges the teachers are facing at private schools was calculated at the significance level of 0.05. in this connection, the value shows that the difference was not significant. Therefore, it is concluded that both the male and female teachers have same sort of experiences with respect to gender.

\section{DISCUSSION}

Job satisfaction plays an important role in overall activity and productivity of school organization and management. The educators' job satisfaction greatly influenced their commitment to the organization. The educators who are satisfied with their work are also committed to work in the organization. The more satisfied the teacher is with job, excellent organizational engagement and commitment, less will be retention (Shila \& Sevilla, 2015). Educators' pleasure or satisfaction with the organization influences their work performance and thus contributes to the success of the school as a whole (Sadasa, 2013). Job satisfaction cannot improve education unless two factors that affect learner performance are improved. It leads to improvement of schools, quality education, and learner satisfaction, which is the ultimate goal of any organization. Additionally, this variable significantly influences leadership behavior, work performance and style (Baluyos et al., 2019).

Most important factors that affect job satisfaction and teachers' retention in any educational institution, especially in private educational institutions, are administrational behavior and teacher salaries (Webb, 2018). Usually, the private educational institutions offer low salaries with more workload. Research studies have indicated that behavior of administration of private education institutions are not according to the satisfaction of teachers (Bakar et al., 2015). To evaluate the factors affecting the retention of teachers in private educational institution, a research study was conducted. The findings of study based on Likert Scale indicated that most of the teachers were not satisfied with the school's administrations, their behaviors and facilitation. The most crucial reason was low salaries of the teachers. The t-test analysis indicated that no significance difference was found between the retention of male and female teachers. The findings of this 
study were as conclusion by (Ballou \& Podgursky, 1998; Fatima, 2015; Faremi, 2017; Kotze, et al., 2020).

\section{CONCLUSION}

Teachers play important role in work of country building for sustainable national development. Teachers are an important element in creating a school environment conducive to teaching and learning. Indeed, recruitment and retention of quality school teachers is critical issue in today's education system. The research study reported in this paper was conducted to find out effects of administration behaviors and facilitations on teachers' views of retention in private schools in Pakistan. Most of teachers indicated that their schools administration cooperates with them. There were many teachers that were not satisfied with this statement. The facilitations were good in schools. The most crucial reason for retention of teachers was their low salaries. T-test analysis looking for potential differences in teachers' views indicated a p value as 0.625 which indicated that no significance difference was found between retention views of male and female teachers.

\section{Recommendations}

The conclusions of this research study would be significantly beneficial for respondent of study, teachers and administration of education institutions, higher education, education practitioners, educational planners and policy makers.

\section{REFERENCES}

Agboola, B., \& Offong, D. E. (2018). Occupational Incentives and Teacher Retention in Private Secondary Schools in Akwa Ibom State, Nigeria. Journal of Teacher Education and Educators, 7(3), 263-277.

Akila, R. (2012). A study on Employee Retention among Executives at BGR energy systems Ltd, Chennai. International Journal of Marketing, Financial Services \& Management Research, 1(9), 18-32.

Akilli, H. I., \& Kingir, S. (2021). The Impact of High-Level Teacher Questioning on Elementary School Students' Achievement, Retention and Attitude in Science. Journal of Education in Science Environment and Health, 7(1), 1-14.

Akram, K., \& Bilal, H. A. (2013) Recruitment and Retention of Generation Y Teachers in Private Educational Sector of Pakistan. International Journal of Humanities and Social Science, 3(15): 227-232.

Arroyo, M. A. (2020). The Relationship Between Teacher Identity and Teacher Retention in Title 1 Schools: A Multiple Case Study. Doctoral dissertation, University of Nevada, Las Vegas.

Bakar, J. A., Mohamad, Z. Z., \& Sharmeela-Banu, S. A. (2015). Factors affecting female lecturer retention in private higher institution in Perak. International Journal of Academic Research in Business and Social Sciences, 5(1), 137.

Ballou, D., \& Podgursky, M. (1998). Teacher recruitment and retention in public and private schools. Journal of Policy Analysis and Management: The Journal of the Association for Public Policy Analysis and Management, 17(3), 393-417.

Baluyos, G. R., Rivera, H. L., \& Baluyos, E. L. (2019). Teachers' job satisfaction and work performance. Open Journal of Social Sciences, 7(08), 206. 
Bogler, R., \& Nir, A. E. (2015). The contribution of perceived fit between job demands and abilities to teachers' commitment and job satisfaction. Educational Management Administration \& Leadership, 43(4), 541-560.

Campoli, A. K. (2017). Supportive principals and black teacher turnover: ESSA as an opportunity to improve retention. Journal of School Leadership, 27(5), 675-700.

Cascio, W. F. (2014). Leveraging employer branding, performance management and human resource development to enhance employee retention. Human Resource Development International, 17(2), 121-128.

Chance, E.W. (1992). Visionary leadership in schools: Success full strategies for developing and implementing an educational vision. Springfield, IL: Charles C. Thomas.

Charlotte Advocates for Education. (2004). Role of principal leadership in increasing teacher retention: Creating a supportive environment. Public Education Network. Available: http://teacherleadership.edc.org/docs/RolePrincipalLeadership.pdf.

Cieminski, A. B. (2018). Practices That Support Leadership Succession and Principal Retention. Education Leadership Review, 19(1), 21-41.

Darling-Hammond, L. (2003). Keeping good teachers: Why it matters, What leaders can do. Educational Leadership, 60, 6-13.

Edworthy A (2000). Managing stress. Buckingham: Open University Press.

Faremi, M. F. (2017). An assesment of teacher retention and job security in private secondary schools in Ogun state, Nigeria. Bulgarian Journal of Science \& Education Policy, 11(2), 279-293.

Fatima, S. A. F. (2015). Comparative Study of Public and Private Educational Institutes towards the Recruitment, Retention and Reward of Their Teachers. Journal of Literature, Languages and Linguistics, 14, 54-62.

Ferlazzo, L. (2015). Response: 'Teachers don't leave high-poverty urban districts; They are exiled'. Education Week Teacher. Retrieved from:http://blogs.edweek.org/teachers/ classroom qa with larry ferlazzo/2015/05/response teachers dont leave highpove rty urban districts they are exiled.htm.

Fessehatsion, P. W., \& Peng, P. (2021). Exploring Teachers' Retention and Attrition in Middle \& Secondary Schools in Eritrea: Perspectives of Currently Serving Teachers. International Journal of Research in Education and Science, 7(1), 227-244.

Godfrey, T. (2010). The relationship between perceived organizational support and turnover intentions in a developing country: The mediating role of organizational commitment. African Journal of Business Management, 4(6), 942-952.

Gomba, C. (2015). Why Do They Stay: Factors Influencing Teacher Retention in Rural Zimbabwe? International Journal of Instruction, 8(2), 55-68.

Government of Pakistan. (2009). The Educational Policy. Islamabad: The Ministry of Education. Hughes, J. N., Cao, Q., West, S. G., Smith, P. A., \& Cerda, C. (2017). Effect of retention in elementary grades on dropping out of school early. Journal of School Psychology, 65, 11-27.

Huysman, J. T. (2007). Rural teacher satisfaction: An analysis of beliefs and attitudes of rural teacher job satisfaction. (Unpublished dissertation, University of Central Florida. Orlando). Retrieved from: http://etd.fcla.edu/CF/CFEo001656/Huysman John T 200705 EdD.pdf.

Jing, L. (2008). Faculty's job stress and performance in the undergraduate education assessment in China: A mixed-methods study. Educational Research and Review, 3(9), 294-300. 
Kimball, S. (2011). Principals: Human capital managers at every school. Phi Delta Kappan, 92(7), 13-18. Retrieved from http://www.jstor.org/stable/25822832.

Kotze, D. M., Mouton, J., Barkhuizen, N., \& de Jager, H. (2020). Talent Retention Of Educators In Selected Private Schools. The International Journal Of Social Sciences And Humanity Studies, 12(2), 306-320.

Lambersky, J. (2016). Understanding the human side of school leadership: Principals' impact on teachers' morale, self-efficacy, stress, and commitment. Leadership and Policy in Schools, 15(4), 379-405.

Lazarus, R., \& Folkman, S. (1984). Stress, appraisal and coping. New York: Springer Publications.

Long, S., Robblee, S., Schaefer, L., Steeves, P., Pinnegar, E., \& Clandinin, D. J. (2012). Literature review on induction and mentoring related to early career teacher attrition and retention. Mentoring \& tutoring: partnership in learning, 20(1), 7-26.

Mugizi, W., \& Dafiewhare, O. A. (2019). Human resource career development practices and retention of secondary school teachers in Rubabo County, Rukungi District, Uganda. Journal of Education Research and Rural Community Development, 1(2), 18-37.

Nguyen, T. D., Pham, L., Springer, M. G., \& Crouch, M. (2019). The Factors of Teacher Attrition and Retention: An Updated and Expanded Meta-Analysis of the Literature. Annenberg Institute at Brown University, 19-149.

Oke, A. O., Ajagbe, M. A., Ogbari, M. E., \& Adeyeye, J. O. (2016). Teacher retention and attrition: A review of the literature. Mediterranean Journal of Social Sciences, 7(2 S1), 371.

Opoku, M. P., Asare-Nuamah, P., Nketsia, W., Asibey, B. O., \& Arinaitwe, G. (2020). Exploring the factors that enhance teacher retention in rural schools in Ghana. Cambridge Journal of Education, 50(2), 201-217.

Pogodzinski, B. (2015). Administrative context and novice teacher-mentor interactions. Journal of Educational Administration, 53(1), 40-65.

Price, J. l. (2001). Reflections on the determinants of voluntary turnover. International Journal of Manpower, 22(7), 660-624.

Property of Charlotte Advocates for Education (2004). Role of principal leadership in increasing teacher retention: Creating a supportive environment. Retrieved from: http://www.educationjustice.org/assets/files/pdf/Resources/Policy/Teaching\%20and\% 20Leadership/Role\%20of\%2opri ncipal\%2oleadership\%2oin\%2oincreasing\%2oteacher \%2oretention.pdf.

Rana, K. (2018). Retention of English language tension in multilingual communities of Nepal: A review of teachers' narratives. Journal of NELTA, 23(1-2), 40-53.

Riggs, L. (2013). Why do teachers quit? And why do they stay? The Atlantic. Retrieved from: https://www.theatlantic.com/education/archive/2013/10/why-do-teachers-quit/28069 9/.

Rose, A. L., \& Sughrue, J. A. (2020). Promoting retention of alternative certified teachers through professional development. NASSP Bulletin, 104(1), 34-54.

Sadasa, K. (2013). The Influence of Organizational Culture, Leadership Behavior, and Job Satisfaction towards Teacher Job Performance. Indian Journal of Health and Wellbeing, 4, 1637-1642.

Samuel, M, O., \& Chipunza, C. (2009). Employee retention and turnover: Using motivational variables as a panacea. African Journal of Business Management, 3 (8), 410-415. 
Schaefer, L., Long, J. S., \& Clandinin, D. J. (2012). Questioning the research on early career teacher attrition and retention. Alberta Journal of Educational Research, 58(1), 106-121.

Shifrer, D., Turley, R. L., \& Heard, H. (2017). Do Teacher Financial Awards Improve Teacher Retention and Student Achievement in Urban Disadvantaged School District? American Educational Research Journal, 54(6), 1117-1153.

Shila, J.M. and Sevilla, A.V. (2015). The Influence of Teachers' Job Satisfaction on Their Organizational Commitment: An Indian Context. International Journal of Education and Management Studies, 5, 53-57.

Sousa-Poza, A., \& Henneberger, F. (2004). Analyzing Job Mobility with Job Turnover Intentions: An International Comparative Study. Journal of Economic Issues, 82, (1) 128.

Tehseen, S., \& Hadi, N. U. (2015). Factors influencing teachers' performance and retention. Mediterranean Journal of Social Sciences, 6(1), 233.

Van Overschelde, J. P., \& Wiggins, A. Y. (2020). Teacher preparation pathways: Differences in program selection and teacher retention. Action in Teacher Education, 42(4), 311-327.

Watson, J. M. (2018). Job Embeddedness May Hold the Key to the Retention of Novice Talent in Schools. Educational Leadership and Administration: Teaching and Program Development, 29(1), 26-43.

Webb, A. W. (2018). Relational-Cultural Theory and Teacher Retention: A Case Study of Relationships and Resilience in Secondary Mathematics and Science Teachers. Journal of Educational Research \& Practice, 8(1), 1-18. 